\title{
PENINGKATAN KETERAMPILAN BERBICARA MENGGUNAKAN MODEL COOPERATIVE SCRIPT
}

\author{
Rahila Salay $^{1)}$, Ade Irma Suryaningsi ${ }^{2)}$, Humaira ${ }^{3)}$, Kiki Rafika ${ }^{4)}$ \\ ${ }^{1,2,3,4)}$ Program Studi Pendidikan Bahasa dan Sastra Indonesia \\ Fakultas Sastra, Universitas Muslim Indonesia \\ Email: rahilasalay97@gmail.com
}

\begin{abstract}
Abstrak: Keterampilan berbicara merupakan salah satu keterampilan berbahasa yang sangat penting dalam kehidupan sehari-hari sebab berbicara merupakan dasar utama dalam berkomunikasi dan berinteraksi di lingkungan. agar interaksi terjalin dengan baik maka perlu adanya komunkasi yang baik pula. karena berkomunikasi bukan hanya sekedar mengucapkan kata demi kata, namun bagaimana seseorang terampil dalam berkomunikasi dengan tujuan agar pendengar mudah memahami dan mengerti apa yang sedang dibicarakan agar tidak terjadi kesalah pahaman. Dengan demikian, keterampilan berbicara sebaiknya lebih ditingkatkan dalam proses pembelajaran disekolah. untuk itu peran guru dalam mengemas perangkat pembelajaran agar tujuan yang ingin dicapai berhasil, salah satu perangkat pembelajaran yaitu pengunaan model pembelajaran yang sesuai dengan materi pembelajaran, khususnya dalam memilih model pembelajaran untuk meningkatkan keterampilan berbicara. Mengapa pemilihan model pembelajaran sangatlah penting, karena keberhasilan seorang guru dalam proses pembelajaran ketika ia kreatif dalam memilih model yang sesuai dengan materi yang akan di ajarkan, nah untuk itu dalam meningkatkan keterampilan bericara dipilihlah salah satu model pembelajaran yang sesuai dengan keterampilan berbicara yaitu model kooperatif dengan tipe kooperatif script yang lebih mengarahkan siswa agar lebih terampil dalam berbicara. Tujuan penulisan yaitu untuk meningkatkan keterampilan berbicara menggunakan model pembelajaran kooperatif script. pada pembahasan akan dibahas bagaimana keterampilan berbicara serta bagaimana model pembelajaran kooperatif script dan peranananya dalam meningkatkan keterampilan berbicara.
\end{abstract}

Kata kunci: keterampilan berbicara, model pembelajaran, cooperative script

\section{PENDAHULUAN}

Keterampilan interaksi mengharuskan pembelajar untuk membuat keputusan tentang komunikasi, seperti apa yang dikatakan, bagaimana mengatakannya, dan apakah yang dikatakan itu akan dijelaskan dan dibicarakan lagi lebih lanjut, sesuai dengan apa yang menjadi maksud dari penutur, dengan tetap menjaga hubungan yang telah terjalin dengan lawan bicara. Perhatikan bahwa konsep tentang mana yang benar dan mana yang salah dalam sebuah percakapan akan sangat tergantung pada apa yang ingin kita katakan, sejauh mana kita berhasil mengatakannya, apakah ada gunanya untuk membicarakan maksud kita itu, apa niatan kita sebenarnya dan jenis hubungan apa yang ingin kita jalin dengan lawan bicara kita (Bygate, 1987).

Untuk meningkatkan kemampuan

bahasa lisan memerlukan pengetahuan tentang bahasa yang digunakan (tata bahasa, kosakata, penggunaan bentuk yang tepat untuk fungsi tertentu), dan keterampilan untuk mengkomunikasikan pesan (penggunaan formula verbal atau penyesuaian terhadap kata-kata lain, mengulang kembali apa yang sudah dikatakan, mengisi kekosongan pembicaraan, sarana-sarana untuk mengungkapkan keraguan). Dalam situasi 
interaksi, siswa harus belajar antara lain bagaimana menegosiasikan makna, bagaimana memperkenalkan atau mengubah topik, bagaimana membuka dan menutup percakapan dengan lawan bicara yang berbeda-beda (Bygate, 1987).

Untuk meningkatkan kemampuan dalam bahasa lisan seorang siswa harus mampu belajar baik secara formal maupun non formal. Karena belajar bisa dilakukan dimana saja dan kapan saja. Dengan belajar maka ada proses yang memungkinkan seseorang memperoleh dan membentuk kompetensi, keterampilan dan sikap yang baru. Sebagaimana yang dijelaskan oleh Bell-Gredler (1986), bahwa belajar sebagai proses perolehan berbagai kompetensi, keterampilan dan sikap. Tentu bagi siswa yang ingin meningkatkan kemampunnya dalam berkomunikasi lisan maupun tulisan maka ia harus banyak menyimak, dan membaca.

Melalui bahasa Indonesia siswa akan belajar bagaimana cara berkomunikasi yang baik dan benar. Komunikasi yang baik dan benar dapat berupa lisan maupun tulisan. Bahasa Indonesia yang berkedudukan sebagai bahasa nasional dan bahasa resmi negara harus terus dibina dan dikembangkan agar menjadi bahasa yang modern, yakni bahasa yang sanggup mengemban fungsinya sebagai sarana komunikasi dalam berbagai segi kehidupan. Dalam usaha membina dan mengembangkan bahasa Indonesia tersebut, pemerintah menjadikan bahasa Indonesia sebagai salah satu bidang studi wajib.

Tujuan pembinaan bahasa Indonesia melalui pendidikan formal tersebut di samping bermaksud agar mahasiswa memiliki keterampilan berbahasa lisan maupun tulisan dengan baik, juga diharapkan memiliki jati diri dan kepribadian yang luhur. Bahasa Indonesia merupakan alat komunikasi bangsa Indonesia secara nasional. Pembelajaran bahasa Indonesia yang baik, diharapkan mampu menghasilkan siswa yang terampil dan menguasai bahasa. Hal ini sejalan dengan pendapat Mansyur (2018) bahwa tujuan pembelajaran bahasa Indonesia tentunya bukan hanya menjadikan peserta didik lulus dalam mata pelajaran Bahasa Indonesia, melainkan mereka harus mampu terampil berkomunikasi menggunakan bahasa Indonesia secara baik dan benar. Mereka dibimbing untuk menguasai aspekaspek keterampilan berbahasa agar dapat menambah pengetahuan dan pengalamannya dalam berkomunikasi sehari-hari.

Keterampilan berbicara merupakan salah satu dari keempat keterampilan berbahasa di jenjang pendidikan formal. keterampilan berbicara merupakan salah satu keterampilan yang memegang peranan penting dalam pembelajaran. Karena keterampilan berbicara adalah media komunikasi lisan yang digunakan dalam kehidupan sehari-hari. dalam proses pembelajaran Siswa tidak akan mampu memahami pelajaran-pelajaran dengan baik ketika komunikasi tidak berjalan baik dan benar karena dalam proses pembelajaran ada interaksi yang terjalin antara guru dan siswa maupun antara sesama siswa, untuk itu keterampilan berbicara berperan penting dalam proses pembelajaran sehingga proses pembelajaran berjalan secara efektif dan efisien.

Dilihat dari aktivitas keseharian siswa, yang sebagian besar waktu yang digunakan adalah berinteraksi dengan teman, guru maupun masyarakat dengan 
cara berkomunikasi lisan, untuk itu kerampilan berbicara harus dimiliki oleh setiap siswa maupun masyarakat agar komunikasi yang terjalin dapat berjalan dengan baik. karena kemampuan berbicara seseorang dapat menjadi daya pemersatu yang ampuh namun kemampuan berbicara juga dapat menjadi pemecah bela dalam suatu kelompok atau antar sesama.

\section{Dalam konteks pembelajaran} berbicara di sekolah, terkadang siswa tidak dilatih dan diarahkan untuk mampu berbicara dengan memperhatikan ketepatan dan kelancaran berbicara. Terkadang aspek yang dipentingkan hanyalah ketuntasan materi pelajaran tanpa memperhitungkan peningkatan kompetensi siswa dalam berbicara, sehingga kemampuan dan pengalaman siswa terhadap keterampilan berbicara hanya sebatas mampu menyampaikan meteri yang diberikan (Umiaty \& Mansyur, 2017:14).

Pembelajaran berbahasa dalam pendidikan formal atau sekolah harus mampu melatih dan membiasakan siswa untuk terampil dalam berbicara. Namun, dalam pengembangan kompetensi percakapan dalam konteks kelas memiliki beberapa kesulitan, terutama karena tiaptiap penutur harus diberi kesempatan untuk berbicara dan harus ada orang yang mendengarkan dan merespon pesan dari pembelajar. Pada saat yang sama, pembelajar harus didorong untuk melakukan komunikasi lewat sistem bahasa yang direduksi/disederhanakan.

Para pembelajar juga perlu diajari bagaimana megatasi kekuragankekurangan pada profisiensi kedua mereka dengan menggunakan strategi-strategi komunikasi, misalnya dengan sirkumlokusi, berbicara berputar, menjelaskan sesuatu dengan kata-kata lain yang lebih banyak jumlahnya, parafrase, gesture/gerak tubuh. Selain itu, siswa juga perlu diberi model-model atau contoh dari gaya interaksi yang sukses yang ditunjukkan lewat media (kaset video dan audio, film, program televise), simulasi percakapan (permainan peran dan sosiodrama) dan kesempatan untuk berinteraksi langsung dengan penutur asli (Scarcella, 1990). Sehingga dalam pembelajaran, kemampuan berbicara merupakan tuntutan utama yang harus dikuasai oleh seorang guru. Jika seorang guru menuntut siswanya dapat berbicara dengan baik, maka guru harus memberi contoh bebicara yang baik. Guru di samping harus menguasai teori berbicara juga terampil berbicara dalam kehidupan nyata. Guru yang baik juga harus dapat mengeskpresikan pengetahuan yang dikuasai dalam bahasa lisan yang baik.

Siswa merupakan komponen utama kerena siswa adalah sebagai subjek pembelajaran. Dalam hal ini guru harus lebih memperhatikan minat siswa, bakat, dan kesulitan yang dihadapi siswa. Mengingat kondisi siswa berbeda-beda, seperti kecerdasannya, latar belakang keluarga serta faktor lain. Sedangkan Guru merupakan komponen penting dalam kegiatan belajar mengajar. Guru mempunyai tugas yang berat. Sehingga guru harus mempunyai kualitas yang tinggi. Guru harus dapat menyusun, melaksanakan, dan mengevaluasi program belajar. Guru harusnya hendak mampu berperan sebagai informator, organosator, moderator, fasilitator, dan evaluator.

Namun pada kenyataannya dalam pembelajaran bahasa Indonesia aspek keterampilan berbicara belum terlaksana dengan baik dan masih dikatakan sangat rendah. Banyak faktor-faktor yang 
mempengaruhi sehingga keterampilan berbicara masih sangat minim atau rendah, diantaranya siswa kurang terlatih dalam berbicara dan juga seorang guru tidak menggunakan model pembelajaran yang baru yang mampu menarik minat dan melatih peserta didik agar senangtiasa berbicara dengan baik dan benar. Karena keterampilan siswa dalam berbahasa terutama dalam berbicara tidak terlepas dari cara mengajar yang baik, suasana kelas yang kondusif, dan strategi pembelajaran yang tepat serta model pembelajaran yang diterapkan. sehubung dengan hal di atas maka penggunaan model pembelajaran harus inovatif agar bisa menarik minat dan mampu melatih siswa dalam berkomunikasi dengan baik dan benar. Kualitas proses pembelajaran diharapkan dapat meningkat dan hasil pembelajaran berupa keterampilan berbicara siswa pun meningkat. Pendekatan dalam pembelajaran berbicara yang digunakan adalah pembelajaran kooperatif, yaitu model cooperative script. Pembelajaran dengan model cooperative script memungkinkan siswa untuk belajar bekerja sama, bertanggung jawab terhadap kelompok, dan belajar keterampilan berkomunikasi. Model cooperative script ialah model belajar siswa bekerja berpasangan dan bergantian secara lisan mengikhtisarkan bagianbagian materi yang dipelajari (Suprijono, 2014:16).

\section{PEMBAHASAN}

\section{Keterampilan Berbicara}

Keterampilan adalah suatu kemampuan dan kapasitas yang diperoleh melalui usaha yang disengaja, sistematis, dan berkelanjutan untuk secara lancar dan adaptif melaksanakan aktivitas-aktivitas yang kompleks. Berbicara adalah suatu alat untuk mengkomunikasikan gagasangagasan yang disusun serta dikembangkan sesuai dengan kebutuhan-kebutuhan si pendengar. Berbicara merupakan instrumen mengungkapkan kepada pendengar hampir secara langsung apakah sang pembicara memahami atau tidak baik bahan pembicaraanya maupun para penyimaknya, apakah dia bersikap tenang serta dapat menyesuaikan diri atau tidak ketika dia mengkomunikasikan gagasangagasannya serta apakah dia antusias atau tidak (Mulgrave, 1954:3-4).

Menurut Mardhiaty \& Mansyur (2018) kemampuan berbicara memiliki peran sentral. Perkembangan intelektual, sosial, dan emosional seseorang sangat dipengaruhi oleh kemampuan berbahasanya. Bahasa diharapkan bisa membantu seseorang untuk mengenal dirinya, budaya, mengemukakan gagasan dan perasaan, berpartisipasi dalam masyarakat. Pengguna bahasa juga diupayakan mampu mengeksplorasi dan menggunakan kemampuan-kemampuan analitis dan imaginatifnya. Demikian halnya dalam proses belajar mengajar di sekolah, diperlukan satu bentuk komunikasi lisan yang akan mengefektifkan pencapaian tujuan pembelajaran.

Dengan demikian, dapat disimpulkan keterampilan berbicara adalah kemampuan mengkomunikasikan gagasangagasan yang disusun serta dikembangkan sesuai dengan kebutuhan-kebutuhan si pendengar melalui usaha yang disengaja, sistematis, dan berkelanjutan. Suatu keterampilan berbahasa yang berkembang pada kehidupan anak, yang didahului oleh keterampilan menyimak dan pada masa tersebut kemampuan berbicara dipelajari. 
Beberapa pakar ahli memberikan defenisi mengenai pengertian keterampilan berbicara di antaranya: Tarigan (1985) yang menyatakan keterampilan berbicara adalah kemampuan mengucapakan bunyibunyi artikulasi atau kata-kata untuk mengekspresikan, menyatakan, serta menyampaikan pikiran gagasan dan perasaan. sebagai perluasan dari batasan ini dapat dikatakan bahwa berbicara merupakan sistem tanda-tanda yang dapat didengar dan yang kelihatan memanfaatkan jumlah otot dan jaringan otot tubuh manusia demi maksud dan tujuan gagasangagasan atau ide-ide yang dikombinasikan.

Lebih jauh lagi dijelaskan bahwa keterampilan berbicara adalah suatu bentuk perilaku manusia yang memanfaatkan faktor-faktor fisik, psikologis, neurologis, semantik, dan linguistik sedemikian ekstensif secara luas sehingga dapat dianggap sebagai alat manusia yang paling penting bagi kontrol sosial.

Kemudian pengertian keterampilan berbicara yang dikemukakan oleh kartini (1985:7) mengungkapkan berbicara adalah suatu peristiwa peyampaian maksud, gagasan, pikiran, perasaan seseorang kepada orang lain menggunakan bahasa lisan, sehingga maksud tersebut dapat di pahami. Pendapat di atas ditambah oleh pendapat yang dikemukakan Laksana (1982:25) bahwa berbicara adalah perbuatan yang menghasilkan bahasa untuk berkomunikasi sebagai salah satu keterampilan dasar dalam berbahasa.

Seanada dengan itu Ahmadi (1984:9) juga memberikan pendapat tentang berbicara yang merupakan suatu keterampilan yang memproduksikan arus sistem bunyi artikulasi untuk menyampaikan kehendak.
Sesuai dengan pendapat di atas maka keterampilan berbicara itu lebih dari sekedar pengucapan bunyi-bunyi atau katakata. Tujuan utama dari berbicara adalah untuk berkomunikasi agar dapat menyampaikan pikiran secara efektif, karena sejatinya sang pembicara memahami makna segala sesuatu yang ingin dan harus mengetahui prinsip-prisip yang mendasari segala sesuatu situasi pembicaraan, baik secara umum maupun perorangan.

Menurut Tarigan, pada dasarnya berbicara mempunyai tiga maksud umum yaitu: (1) memberitahukan dan melaporkan (to inform), 2) menjamu dan menghibur (to entertain), 3) membujuk, mengajak, mendesak, dan meyakinkan (to persuade). Menurut Ochs \& Winker, (1979:9), gabungan dari maksud-maksud itu mungkin saja terjadi. suatu pembicaraan misalnya mungkin saja merupakan gabungan dari meloporkan dan menjamu begitu pula mungkin sekaligus menghibur dan meyakinkan.

Berbicara merupakan sarana kita berkomunikasi satu sama lain. Hal ini dapat dilihat dari fungsi bahasa, antara lain: (1) Bahasa sebagai sarana komunikasi, yaitu kita tahu bahwa bahasa merupakan sarana kita untuk melakukan komunikasi satu sama lain, (2) Bahasa sebagai sarana integrasi dan adaptasi, yaitu dengan bahasa orang dapat menyatakan hidup bersama dalam suatu ikatan, misalnya pekerjaan, integritas kerja suatu instansi atau karyawan, (3) Bahasa sebagai sarana kontrol sosial, yaitu bahasa berfungsi untuk mengendalikan komunikasi agar orang yang terlibat dalam komunikasi dapat saling memahami, (4) Bahasa sebagai sarana memahami diri, yaitu bahasa dalam membangun karakter seseorang harus 
dapat memahami dan mengidentifikasi kondisi dirinya sendiri, (5) Bahasa sebagai sarana ekspresi diri, yaitu bahasa dapat digunakan untuk mengekspresikan diri misalnya menyatakan cinta, (6) Bahasa sebagai sarana memahami orang lain, yaitu untuk menjamin efektivitas komunikasi. Untuk meningkatkan keterampilan berbicara dalam proses pembelajaran di dalam kelas guru harus kreatif dalam memilih model pembelajaran sehingga tujuan yang ingin dicapai dapat terlaksana.

\section{Model Pembelajaran}

Para ahli menyusun model pembelajaran berdasarkan prinsip-prinsip pembelajran, teori-teori psikologis, sosiologis, analisis sitem, atau teori-teori lain yang mendukung (Joyce \& Weil, 1980). Joyce \& Weil mempelajari modelmodel pembelajaran berdasarkan teori belajar yang dikelompokkan menjadi empat model pembelajaran. Model tersebut merupakan pola umum perilaku pembelajaran untuk mencapai tujuan pembelajarn yang diharapkan.

Joyce \&Weil berpendapat bahwa model pembelajran adalah suatu rencana atau pola yang dapat digunakan untuk membentuk kurikulum (rencana pembelajaran jangka panjang), merancang bahan-bahan pembelajaran, dan membimbing pembelajarn di kelas atau yang lain (Joyce \& Weil, 1980:1).

Model pembelajaran dapat jadikan pola pilihan, artinya para guru boleh memilih model pembelajaran yang sesuai dan efisien untuk mencapai tujuan pendidikannya. Model pembelajaran adalah seluruh rangkaian penyajian materi ajar yang meliputi segala aspek sebelum sedang dan sesudah pembelajaran yang dilakukan guru serta segala fasilitas yang terkait yang digunakan secara langsung atau tidak langsung dalam proses belajar mengajar.

Model pembelajran juga megacu pada pendekatan pembelajaran yang akan digunakan, termasuk di dalamnya terdapat tujuan-tujuan pengajaran, tahap-tahap dalam kegiatan pembelajran, lingkungan pembelajaran dan pengolaan kelas (Arends, 1997:7). Fungsi model pembelajaran adalah sebagai pedoman bagi pengajar dan para guru dalam melaksanakan pembelajaran. Hal ini menunjukkan bahwa setiap model yang akan digunakan dalam pembelajaran menentukan perangkat yang dipakai dalam pembelajaran tersebut.

Arends memiliki istilah model pembelajaran berdasarkan dua alasan penting, yaitu pertama, istilah model mempunyai makna yang lebih luas dari pada strategi, metode, atau prosedur. Kedua, model dapat berfungsi sebagai sarana komunikasi yang penting, apakah yang diibicarakan tentang mengajar di kelas, atau praktik mengawasi anak-anak. Model pembelajaran mempunyai empat ciri khusus yang tidak dimiliki oleh strategi, metode, atau prosedur. Ciri-ciri tersebut antara lain:

1. Rasional teoritik yang logis, disusun oleh para pencipta atau pengembangnya.

2. Landasan pemikiran tentang apa dan bagaimana siswa belajar (tujuan pembelajaran yang akan dicapai).

3. Tingkah laku mengajar yang diperlukan agar model tersebut dapat dilaksanakan dengan berhasil.

4. Lingkungan belajara yang diperlukan agar tujuan pembelajaran itu dapat tercapai (Kadir \& Nur, 2009). 
Model Pembelajaran Cooperative Script

Model pembelajaran dapat diartikan sebagai cara yang digunakan untuk mengimplementasikan rencana yang sudah disusun dalam bentuk kegiatan nyata dan praktis untuk mencapai tujuan pembelajaran. Pembelajran kooperatif adalah strategi pembelajran yang melibatkan partisipasi siswa dalam satu kelompok kecil untuk saling berinterakssi (Nurulhayati, 2002:25). Dalam sistem belajar yang kooperatif, siswa belajar bekerja sama dengan anggota lainnya. Dalam model ini siswa memiliki dua tanggung jawab, yaitu mereka belajar untuk dirinya sendiri dan membantu sesama anggota kelompok untuk belajar. Siswa belajar bersama dalam sebuah kelompok kecil dan mereka dapat melakukannya seorang diri.

Pembelajarn kooperatif tidak sama dengan sekadar belajar dalam kelompok. Ada unsur dasar pembelajaran kooperatif yang membedakan dengan pembelajaran kelompok yang dilakukan asal-asalan. Pelaksanaan prinsip dasar pokok sistem pembelajaran kooperatif dengan benar akan memungkinkan guru mengelola kelas dengan lebih efektif. Dalam pembelajaran kooperatif proses pembelajran tidak harus belajar dari guru kepada siswa. Siswa dapat saling membelajarkan sesama siswa lainnya. Pembelajaran oleh rekan sebaya (peertaching) lebih aktif dari pada pembelajaran oleh guru.

Ada beberapa tipe dalam pembelajaran kooperatif yang dapat digunakan oleh guru dalam proses pembelajaran untuk meningkatkan keterampilan berbicara, salah satunya adalah model pembelajaran koopertif script. Model pembelajaran kooperatif script siswa akan terlatih mengembangkan ide-idenya sehingga siswa dapat mengontruksi sendiri pengetahuannya. Model ini juga akan melatih aktifitas belajar sehingga setiap siswa mempunyai tugas dalam proses pembelajaran berlangsung.

Proses siswa bekerja sama untuk berpasangan dan bergantian untuk mendefiniskan bagian inti materi yang akan di pelajari. Pendapat tersebut senada menurut Suprijono, (2014:126) “ kooperatif script merupakan metode belajar dimana siswa bekerja berpasangan dan bergantian secara lisan mengikhtisarkan bagian-bagian dari materi yang dipelajari." Huda (2014:213) juga menyatakan model pembelajaran kooperatif script adalah salah satu strategi pembelajaran bagi siswa bekerja secara berpasangan dan bergantian materi yang dipelajari. Hal ini juga sependapat dengan Andayani (2015:242) memaparkan bahwa model pembelajaran yang diterapkan dengan cara siswa bekerja secara berpasangan dan bergantian secara lisan dalam mengikhtisarkan bagian materi-materi yang dipelajari.

Berdasarkan pendapat para ahli di atas dapat disimpulkan bahwa model pembelajaran kooperatif script adalah kerja sama dalam belajar dan membuat ringkasan atau mengikhtisarkan suatu ide pokok materi yang sedang dipelajari, selain itu siswa belajar menghargai pendapat pasangannya.

$$
\text { Menurut Suprijono (2014:126) }
$$
cooperative script adalah metode belajar siswa bekerja berpasangan dan bergantian secara lisan mengikhtisarkan bagian-bagian materi yang dipelajari. Pembelajaran ini menuntut siswa untuk bertanggung jawab terhadap kelompok, berpandangan bahwa 
memiliki tujuan yang sama, dan berbagi kepemimpinan dalam kelompok.

Implementasi model cooperative script ini adalah sebagai berikut. Pertama, guru membagi siswa untuk berpasangan. Kedua, guru membagikan wacana atau materi kepada setiap siswa untuk dibaca dan membuat ringkasan. Ketiga, guru dan siswa menetapkan siapa yang berperan sebagai pembicara dan siapa yang berperan sebagai pendengar. Keempat, pembicara membacakan ringkasannya kurang lengkap dan membantu mengingat/menghapal ideide pokok dengan menghubungkan materi sebelumnya atau dengan materi lainnya. Kelima, bertukar peran. Siswa yang semula sebagai pembicara ditukar menjadi pendengar dan sebaliknya. Keenam, siswa membuat kesimpulan bersama dengan guru. Ketujuh, penutup, siswa melakukan refleksi bersama guru.

\section{KESIMPULAN}

Keterampilan berbicara adalah sekedar bunyi-bunyi atau kata-kata yang bertujuan untuk menyampaikan pikiran secara efektif, karena dengan berbicara dapat memahami makna segala sesuatu, terdapat pula manfaat dari berbicara dengan menggunakan macam-macam bahasa: (1) sebagai sarana memahami diri; (2) sebagai sarana ekspresi diri; dan (3) sebagai sarana memahami orang lain. Keterampilan berbicara dalam sebuah proses pembelajaran guru harus kreatif dalam menggunakan sebuah model pembelajaran sehingga tujuan pembelajaran dapat tercapai.

Untuk meningkatkan keterampilan berbicara dalam sebuah proses pembelajaran disini guru dapat menggunakan model cooperative script. Model ini bertujuan agar siswa dapat berproses di dalam kelas dengan bekerja sama untuk berpasangan dan bergantian mendefinisikan materi bagian inti. Siswa juga dapat memasukkan ide-ide atau gagasan baru dalam materi ajar dan siswa dpat saling melengkapi satu sama lain.

Dalam model pembelajaran cooperative script semua siswa berperan aktif dalam proses pembelaran sehingga siswa dapat memahami pelajaran lebih mudah. dalam cooperative script ini mengandung suatu unsur kerjasama dalam kelompok yang membuat siswa berperan aktif dalam pembelajaran bukan seorang guru. Guru bertindak sebagai fasilitator untuk mengarahkan dan memotivasi bagi siswa.

\section{DAFTAR PUSTAKA}

Ahmad, Abd Kasim \& Mariona. 2017. Penerapan Model Pembelajaran Coopertive Script dalam Kemampuan Membaca Bahasa Jerman Siswa Kelas XI IPA MAN 1 Makassar. Jurnal Pendidikan Bahasa Asing dan Sastra, 1(2), 148-149.

Ghazali, Abd. Syukur. 2013. Pembelajaran Keterampilan Berbahasa. Bandung: PT Refika Pratama.

Huki, Luci. 2016. Arti dan Pengertian tentang Segala Sesuatu (Pengertian Keterampilan). (Online, http://artidanpengertian.blogspot.com/, Diakses 19 Desember 2018).

Khodijah, Yayu. 2016. Psikologi Pendidikan. Jakarta: Rajawali Pers.

Mansyur, Umar. 2018. Sikap Bahasa dan Pembelajaran Bahasa Indonesia di Perguruan Tinggi. In 1st International Conference of Asosiasi Linguistik Terapan Indonesia UMI 2018. https://doi.org/10.31227/osf.io/te3df. 
Mardhiati, Ayinun, \& Mansyur, Umar. 2018. Teknik Total Physical Respons untuk Meningkatkan Kemampuan Berbicara Anak Tunarungu. INA-Rxiv. https://doi.org/10.31227/osf.io/8czqb.

Matsuri, Yustinus Ngadino \& Azzizah, Nurlaili. 2014. Peningkatan Keterampilan Berbicara dengan Menggunakan Model Pembelajaran Kooperatif Tipe Cooperative Script. (Artikel), Halaman 1-2.

Reira, Wibowo. 2013. Model-model Pembelajaran. (Online, www.academia.edu., Diakses 19 Desember 2018).

Rusman. 2016. Model-Model Pembelajaran. Jakarta: Rajawali Pers.

Tarigan, Henry Guntur. 2008. Berbicara Sebagai Suatu keterampilan Berbahasa. Bandung: Angkasa

Umiaty, Muli, \& Mansyur, Umar. 2017. Learning Community dalam Pembelajaran Keterampilan Berbicara Bahasa Inggris Siswa Kelas XII SMA LPP UMI Makassar. Retorika: Jurnal Bahasa, Sastra, dan Pengajarannya, 10(1), 13-19. 